\title{
Grazing of Native Livestock Breeds as a Method of Grassland Protection in Roztocze National Park, Eastern Poland
}

\author{
Mariusz Kulik' , Marianna Warda' ${ }^{1}$ Adam Gawryluk ${ }^{1 *}$, Andrzej Bochniak², \\ Krzysztof Patkowski ${ }^{3}$, Antoni Lipiec ${ }^{4}$, Tomasz Gruszecki ${ }^{3}$, Michał Pluta ${ }^{5}$, \\ Elżbieta Bielińska ${ }^{6}$, Barbara Futa ${ }^{6}$ \\ 1 Department of Grassland and Landscape Forming, University of Life Sciences in Lublin, Lublin, Poland \\ 2 Department of Applied Mathematics and Computer Science, University of Life Sciences in Lublin, Lublin, \\ Poland \\ 3 Department of Small Ruminants and Agriculture Advisory, University of Life Sciences in Lublin, Lublin, Poland \\ ${ }^{4}$ Institute of Animal Nutrition and Bromatology, University of Life Sciences in Lublin, Lublin, Poland \\ 5 Department of Horse Breeding and Use, University of Life Sciences in Lublin, Lublin, Poland \\ ${ }^{6}$ Institute of Soil Science, Environment Engineering and Management, University of Life Sciences in Lublin, \\ Lublin, Poland \\ * Corresponding author's e-mail: adam.gawryluk@up.lublin.pl
}

\begin{abstract}
The studies were conducted in a forest settlement in Roztocze National Park (eastern Poland). The aim of the study was to evaluate the vegetation of two pastures depending on the type of use in the context of grassland protection, identify the trends of species composition changes, and analyse the yield and nutritional value of the biomass in the context of animal welfare. The studies were conducted on permanent grasslands varying in terms of fertility and location. Both sites were pastures where native breeds of livestock (Polish Lowland sheep of the Uhrusk and Polish Konik) were grazing. The fertile pasture was represented by the developing Lolio-Cynosuretum association, while the poor dry pasture - by a community with Common Bent (Agrostis capillaris L.) and a community with Mouse-Ear Hawkweed (Hieracium pilosella L.). The greatest changes over time were observed in the mowed site in the fertile pasture (increased share of tall grasses) and in the abandoned poor dry pasture (increased share of herbs and weeds). Livestock grazing conducted from 2010 influenced the stabilisation of the species composition. Tree and shrub seedlings were systematically eaten by livestock, which evidences a positive impact of grazing on the preservation of permanent grasslands in Roztocze National Park where forest ecosystems predominate. The assessment of the species composition and yielding indicated that the fertile pasture was characterised by good value while the poor pasture - low or sufficient value. In terms of nutrient yield and content, these pastures were poor or very poor, and their nutritive potential was largely dependent on the meteorological conditions. While the livestock density in the pastures, ranging from 1.1 to $1.5 \mathrm{LSU} \mathrm{ha}^{-1}$ in the years under study, was appropriate, grazing should be limited in the summer months, particularly in periods of drought, by reducing the number of animals or by additional feeding to ensure their welfare.
\end{abstract}

Keywords: animal welfare, grasses, herbs and weeds, horses, sheep

\section{INTRODUCTION}

Permanent grasslands are among the most endangered non-forest ecosystems in the world. They are semi-natural habitats, dependent on appropriate use and management. Pastures whose vegetation is considerably influenced by livestock are a peculiar type of grassland. Pastures have an important role in the preservation of biodiversity, providing habitat for many rare plants and animals (Benthien et al. 2018; Dostálek and Frantík, 2008; Töröka et al. 2016; Warda et al. 2011). 
The acreage of pastures in Europe has decreased considerably during the last several decades as a result of changes in land use, including the abandonment of grazing, secondary succession, or the reforestation of land on poor soils (Chabuz et al. 2019; Dostálek and Frantík, 2008; Kulik, Warda, and Leśniewska, 2013; Nienartowicz et al. 2015; Sewerniak and Jankowski, 2015; Steinshamn et al. 2018). That is when undesirable plant species, including alien invasive species, can appear in the sward of the pastures. Lowyield pastures located on poor dry soils or with difficult to access are the first to be excluded from agricultural use. Native livestock species, hardy and resilient to difficult habitat conditions, are the most suitable for such pastures (Chabuz et al., 2019; Kulik et al., 2013; Lipiec et al. 2015; Steinshamn et al., 2018; Süss and Schwabe, 2007).

Livestock grazing brings a lot of benefits to environmentally valuable habitats, animals in the pastures as well as farmers. Animals ingest goodquality feed while the fresh air and sunlight increase the absorption of vitamin D3 and are conducive to the mineralisation of bones, particularly in young animals (Patkowski et al. 2018; Pluta and Osiński, 2018). Some animals species, particularly horses, eat plants selectively or choose specific parts of pastures where they obtain feed. They do not like to grazing in areas where they excrete faeces. This has an impact on the vegetation cover of these pastures. That is why, whenever possible, it is recommended to alternate the grazing of sheep or cattle with other animals, which increases the utilisation of the sward and reduces the likelihood of infection with intestinal parasites (Pilliner, 2008). Shared grazing also influences the biological and structural development of the soil (Futa et al. 2016). Roztocze National Park is one of the areas where various native livestock breeds are grazed in order to protect permanent grasslands against secondary succession.

The aim of the study in Roztocze National Park was to (1) analyse the species composition of two pastures depending on the type of use in the context of grassland protection, (2) identify the trends of flora changes, and (3) analyse the yield and nutritional value of the biomass in the context of animal welfare.

\section{MATERIALS AND METHODS}

\section{Study area}

Located in eastern Poland, Roztocze National Park was established in 1974 to protect diverse forest ecosystems of Central Roztocze. Many rich forest plant communities occur there. Forests cover $93.81 \%$ of the Park's area. The remaining area is covered by non-forest ecosystems, among which permanent grasslands predominate. Some of them constitute valuable natural habitats within the Natura 2000 network.

The studies were conducted in Florianka $\left(22^{\circ} 58-59^{\prime} \mathrm{E}, 50^{\circ} 33^{\prime} \mathrm{N}\right)$, a forest settlement of the former Zamoyski Estate, on the edge of the Zwierzyniec forest.

\section{Field study}

The studies were conducted in the years 2014-2017 on permanent grasslands varying in terms of fertility and location (1. fertile habitat; 2 . poor habitat). Both sites under study were pastures where native breeds of livestock were grazing. The Polish Lowland sheep of the Uhrusk variety, bred for the needs of Central-Eastern Poland, was the main species. Another species was the Polish Konik whose preservation breeding is conducted in Zwierzyniec, in Roztocze National Park. It is a native horse breed characterised by good health, hardiness and adaptation capacity (Gruszecki et al. 2013; Patkowski et al. 2018). Various types of use were pursued on both pastures: 1 . fertile pasture $(1 \mathrm{a}$ - sheep and horses grazing; $1 \mathrm{~b}$ - sheep grazing; $1 \mathrm{c}-$ mowing); 2 . poor dry pasture $(2 \mathrm{a}-$ lack of grazing; $2 b$ - sheep grazing; $2 c$ - sheep grazing). Fertile pastures (sites 1a, 1b, 1c), with an area of 2.0 ha, comprised three sections that used to function as hay meadows established on former agricultural land in 1996. In two sections, $(1 \mathrm{a}, 1 \mathrm{~b})$, native breeds of livestock were grazed from 2010, while the third one was mowed (1c). Sand calcareous grasslands grew on poor dry pastures (sites $2 \mathrm{a}, 2 \mathrm{~b}, 2 \mathrm{c}$ ), covering $2.5 \mathrm{ha}$, and sheep grazing was commenced there in $2010(2 b, 2 c)$. An area of about 1.2 ha was covered by swards with a high concentration of trees, particularly Pinus sylvestris. Part of the pasture was fenced off, and no actions were carried out there (1a).

In the years 2014-2017, sheep grazing began in the first 10 days of May and lasted until the end of October. The sheep stayed from 7:30 am until $2: 30 \mathrm{pm}$ in the first site $(1 \mathrm{a}, 1 \mathrm{~b})$, and then they were driven to the other pasture $(2 \mathrm{a}, 2 \mathrm{c})$ where they stayed until 7:00 pm. The animals stayed in the sheepfold during the night. The herd consisted of two rams, 25-39 ewes, and 29-55 lambs, which corresponds to 5.1-6.8 LSU. In section 1a, four Polish koniks, weighing from 380 to $440 \mathrm{~kg}$, 
were grazing for 15 days per year. Considering the area of both pastures, the livestock density index ranged from 1.1 to $1.5 \mathrm{LSU} \mathrm{ha}^{-1}$.

In 2014, general floristic surveys were conducted using the Braun-Blanquet method (1964) by making six phytosociological relevés in an area of $25 \mathrm{~m}^{2}$ in representative places within the designated sites (1abc, 2abc). The phytosociological taxonomy was based on Matuszkiewicz (2008), and the species names were provided according to Mirek et al. (2002). In each site, $1 \mathrm{~m}^{2}$ plots in three replications were designated to assess the species composition using the quadrat method. Representative samples of green biomass from two pastures were collected in late May and early June in 2016 and 2017 from an area of $1 \mathrm{~m}^{2}$, in three replications. The averaged samples subjected to chemical analyses to identify the content of dry matter, crude protein, crude fibre and crude fat. The results of the analyses were used to assess the dietary value of the green biomass in MJs of metabolisable energy, UFL (unité fourragère lait) $=$ feed unit for lactation (Jarrige, 1989) and net energy fattening - MJs NET (Dobrowolska, 1993). Samples were also collected from the same plots from the second (end of July and early August) and third (September) regrowth to estimate the yield potential of pastures. Based on the yield potential and animals' capacity to consume the diet, we have recommended the population size (in livestock units: $\mathrm{LSU} \mathrm{ha}{ }^{-1}$ ), with regard to dietary welfare.

\section{Data analysis}

The differences in the chemical composition based on dry matter were analysed by means of ANOVA and Tukey's test $(p \leq 0.05)$ to identify groups with significantly different mean parameter values. The comparisons took into account the division into four groups depending on the pasture (fertile and poor) and study period (2014-2015 and 2016-2017). Due to the distortion of assumption of the homogeneity of variance in groups for certain parameters: ashes, gross energy - GE (MJ), metabolisable energy - EM (MJ), the analysis was carried out for logarithmised values.

In addition, multidimensional principal component analysis - PCA (Jolliffe, 2002) was carried out to detect the variation of species composition of the dataset analysed. The first PCA concerned functional groups of plants: grasses, legumes, sedges and rushes, herbs and weeds, mosses. The second PCA took into account the division of plants based on their value according to Filipek (1973): very good, good, sufficient, low and not included.

The PCA method makes it possible to determine which groups of plants influenced the variation of species composition as well as to visualise species composition depending on the pasture and study period. Owing to the similar scale of the shares, the covariance matrix was used to estimate the principal components. All statistical analyses were carried out using StatSoft Statistica ver.13.1.

\section{RESULTS AND DISCUSSION'}

\section{Vegetation changes}

The phytosociological surveys conducted in the pastures indicated plant communities belonging to two classes. The fertile pasture is represented by the developing Lolio-Cynosuretum association with a small share of grassland species. It should be noted that mowed meadows were established on former agricultural land by sowing a mixture of grasses and legumes in 1996, while the grazing of sheep began in 2010. The factors mentioned above as well as the gradient of the slope on which livestock graze have a huge impact on changes of the vegetation cover and the production potential. The second pasture, located on a flat area, features sand calcareous grasslands from the Koelerio glaucae-Corynephoretea canescentis class. The community with Common Bent (Agrostis capillaris L.) and community with Mouse-Ear Hawkweed (Hieracium pilosella L.) predominate. These grasslands had not been used previously, and grazing there began in 2010 as well.

The dominant species in the sward of the first pasture were White Clover (Trifolium repens L.), Common Meadow Grass (Poa pratensis L.) and (Taraxacum officinale F.H. Wigg.), while the co-dominant species were Dactylis glomerata, Poa trivialis, Lolium perenne and Festuca arundinacea. The dominant species in the sward of the second pasture were Agrostis vulgaris, Cirriphyllum piliferum, Achillea millefolium and Hieracium pilosella. It should be noted that Cirriphyllum piliferum moss, which was not ingested by sheep, had a high cover-abundance. Hypochaeris radicata and Poa pratensis had a smaller share (Table 1). 
No considerable changes were observed in the number of species in the two periods analysed, except for the mowed site (1c) and the grassland whose use was discontinued (2a). Lolium perenne and Poa pratensis are typical pasture grasses characterised by very good nutritional value and willingly ingested by livestock, including horses (Allen, Sheaffer, and Martinson, 2013). Various farm animal species have different ways of foraging for pasture sward. Horses graze plant species in the pasture selectively. The species most preferred by horses are Festuca pratensis, Lolium perenne, Dactylis glomerata and Trifolium repens (Allen et al., 2013; Chabuz et al., 2019). Herbs also play a significant role in the nutrition of horses. One of such herbs is Taraxacum officinale (Paskudska, Kołodziejczyk, and Socha, 2018), characterised by high cover-abundance, particularly in the fertile pasture (Table 1).

While nibbling vegetation, horses slightly draw on some tufts and, due to their greater weight, have a stronger impact on the habitat. Sheep, on the other hand, nibble at the lowest parts of the sward, treading on the dead organic matter and upsetting the soil. Similarly to horses, they first select plants that they prefer the most. However, all livestock species can complement each other thanks to their different impact on the habitat (Barańska, Żmihorski, and Pluciński, 2013). To maintain floristic diversity, different grazing systems, alternating in time and space, should be used (Chabuz et al., 2019; Töröka et al. 2016).
It should be noted that tree and shrub seedlings were not observed in the sward of the pastures because they were systematically nibbled by the grazing livestock. The only species from this group were tall trees occurring in the poor dry pasture, mainly Pinus sylvestris, in whose shade the sheep found shelter on hot days.

Analyses of the species composition of the pastures depending on the type of use revealed certain changes in the two periods analysed (2014-2015 and 2016-2017). The analysis of functional plant groups showed that the first two principal components account for $85.71 \%$ of the variation of the dataset (Figure 1). The values of the first component are mainly correlated with the share of herbs and weeds (positive correlation) and grasses and legumes (negative correlation). The values of the second component are positively correlated with the share of grasses and negatively with the share of legumes. The pastures differ most by the values of the first component. A greater share of grasses and legumes was observed in the sward of the fertile pasture, while herbs and weeds - in the sward of sand calcareous grassland. It is worth noting the increasing share of grasses in the mowed section (1c) of the fertile pasture in the years of the study (Figure 1).

These were mainly Dactylis glomerata and Festuca arundinacea whose share increased as a result of mowing (Table 1). Mowing is conducive to tall grasses while grazing results in their disappearance and appearance of low grasses (Allen et al., 2013; Chabuz et al. 2019). Under grazing conditions (sites 1a and 1b), the differences are

Table 1 Mean share of dominant species (\%)

\begin{tabular}{|c|c|c|c|c|c|c|c|}
\hline \multirow{2}{*}{ Species } & \multirow{2}{*}{ NUV } & \multicolumn{3}{|c|}{ Pasture 1} & \multicolumn{3}{|c|}{ Pasture 2} \\
\hline & & $1 a$ & $1 \mathrm{~b}$ & 1c & $2 a$ & $2 b$ & $2 c$ \\
\hline Trifolium repens & 10 & 33.4 & 32.8 & 14.1 & 0.7 & 1.3 & 0.4 \\
\hline Poa pratensis & 10 & 16.8 & 12.2 & 10.5 & 8.0 & 6.6 & 5.1 \\
\hline Taraxacum officinale & 6 & 8.5 & 10.1 & 8.4 & 1.1 & 1.0 & 0.4 \\
\hline Dactylis glomerata & 9 & 5.0 & 2.6 & 13.4 & 0.0 & 0.6 & 0.1 \\
\hline Poa trivialis & 7 & 6.0 & 9.4 & 5.0 & 0.0 & 0.0 & 0.0 \\
\hline Lolium perenne & 10 & 7.9 & 10.1 & 4.6 & 0.0 & 0.0 & 0.0 \\
\hline Festuca arundinacea & 6 & 1.0 & 0.0 & 14.1 & 0.0 & 0.0 & 0.0 \\
\hline Agrostis vulgaris & 6 & 0.8 & 1.8 & 0.6 & 28.2 & 30.3 & 21.7 \\
\hline Cirriphyllum piliferum & - & 2.1 & 3.1 & 2.9 & 3.7 & 11.4 & 25.1 \\
\hline Achillea millefolium & 6 & 2.9 & 0.0 & 6.0 & 20.8 & 16.5 & 6.8 \\
\hline Hieracium pilosella & 2 & 0.0 & 0.0 & 0.0 & 1.5 & 2.2 & 18.3 \\
\hline Hypochaeris radicata & 1 & 0.0 & 0.0 & 0.0 & 1.3 & 9.6 & 4.0 \\
\hline $\begin{array}{l}\text { Total number of species } \\
\text { 2014-2015 (2016-2017) }\end{array}$ & & $23(22)$ & $20(20)$ & $25(19)$ & $22(20)$ & $27(26)$ & $12(12)$ \\
\hline
\end{tabular}

NUV - number of use value according to Filipek (1973): 10-9: very good; 8-7: good; 6-4: sufficient; 3-1: low 


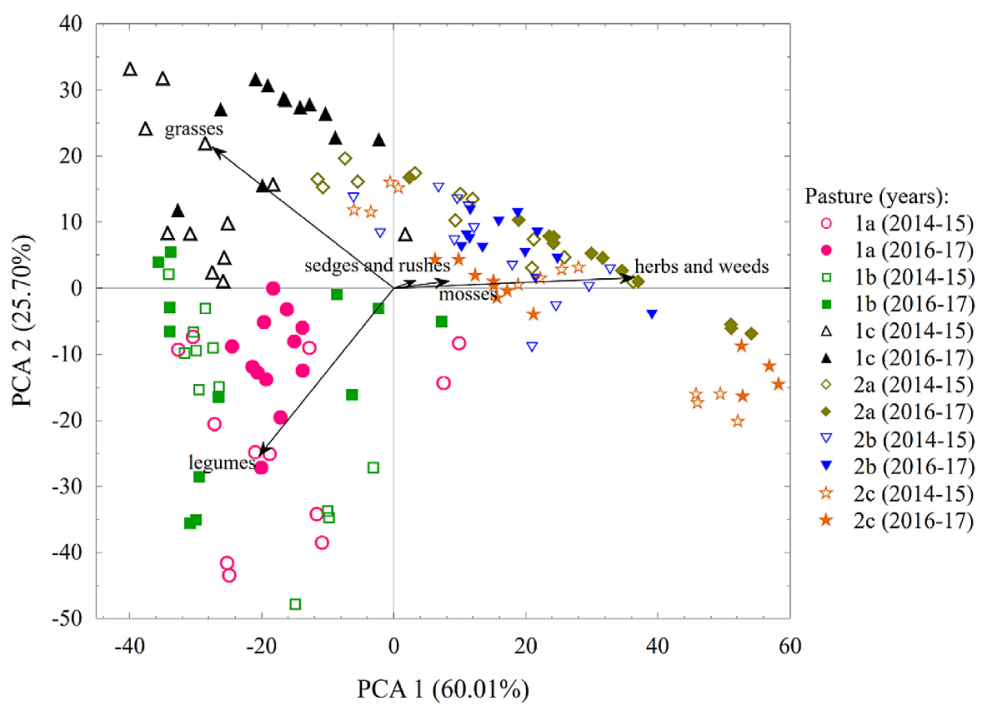

Figure 1. Principal Component Analysis (PCA) ordination graph of functional plant groups depending on the pasture and study period

small, which indicates a small influence of the grazing horses on changes in the species composition. The observed differences worth mentioning include a slightly greater share of Trifolium repens and Bellis perennis appearing in the second period. These are typical pasture species, closely associated with pastures for horses (Allen et al., 2013; Matuszkiewicz, 2008). In the other pasture, no changes were observed in the years under study, except for the lack of use in site $2 b$ where an increased share of species from the herb and weed group was observed. In some sites (1a and $2 \mathrm{~b}$ ), a smaller spread of points was observed in the second period (2016-2017) in comparison to 2014-2015. This can be a sign of a certain stabilisation of the species composition as a result of various environmental factors. The animals consume not only grasses, but also shrubs and trees, which inhibits overgrowing and secondary succession. It also improves the rooting and propagation of plants and stimulates their growth (Aldezabal et al. 2015).

\section{Biomass value}

The PCA carried out to assess the variation of the species composition depending on the value of the sward according to Filipek (1973) accounts for its variation to a greater extent. The first two principal components account for $90.45 \%$ of the variation of the dataset. Species of very good or sufficient value are characterised by the biggest share in the first principal component (PCA1), while species of low and sufficient value - in the second principal component (PCA2). The biggest share of species of very good value was observed in the sward of the fertile pasture 1a and $1 b$ (Figure 2). In the case of mowing (site 1c), the number of species of very good value decreased while the number of those of sufficient value increased in the periods under study. This indicates a positive influence of grazing on the share of valuable species. In the case of sites subjected to grazing, no changes were observed both in the case of sheep grazing and mixed grazing. This indicates a certain stabilisation of the species composition and the persistence of species of very good nutritional value. In the case of mixed grazing (sheep + horses), a smaller variation of the first principal component was observed.

Different trends were observed in the poor dry pasture. The biggest share of species of low value was observed in section $2 \mathrm{c}$, while species of sufficient value had a greater share in section $2 b$. The smallest variation was observed in the unused section (2a), but an analysis of changes over time shows that the lack of use influenced the increasing share of species of low functional value (Figure 2). The abandonment of use, including grazing, results in changes in the species composition manifested in the appearance or increased cover-abundance of species of low nutritional value to livestock (Chabuz et al., 2019; Dostálek and Frantík, 2008; Kulik et al., 2013; Steinshamn et al., 2018).

A comparison of the value of both pastures shows that the fertile pasture contained more plants of good or very good value, while the 
poor pasture featured more species of sufficient or low value. The abundance of macro-elements and the enzymatic activity of the soil are the factors observed in this case (Futa et al., 2016). Sand calcareous grasslands usually feature species of low value and of low aboveground biomass yield (Benthien et al. 2018; Dostálek and Frantík, 2008; Kulik et al., 2013; Süss et al. 2004; Warda et al. 2011).

Protein content in the biomass analysed ranged from 12.64 to $19.70 \%$ depending on the pasture and study year (Table 2). Greater significant differences were observed in crude fibre content. A significantly higher content of this nutrient was recorded in 2017, which indicates a strong influence of meteorological conditions and the vegetation development phase. An analysis of the yield of nutrients (dry mass, UFL and protein), pasture 1 has to be regarded as poor despite the relatively high biomass yield $\left(6.2-6.5 \mathrm{t} \mathrm{ha}^{-1}\right)$ and pasture 2 as poor (Gaweł et al. 2016; Szajda and Łabędzki, 2016). Yield is an important criterion for choosing forage for animals, but it is only one factor in a complex system which also includes water-use efficiency, nutritive value, costs of production and risk (Neal et al. 2009). On the other hand, when we look at grasslands as valuable habitats (Dostálek and Frantík 2008; Gallet and Roze, 2001; Kulik et al., 2013; Süss et al., 2004), the nutritive value is less important. This negative assessment is also linked with the low energy and protein content in dry mass (Jarrige,
1989). A low amount of energy in dry mass also influences a low supply of protein digested in the small intestine (PDI). This results from the fact that in the years 2016-2017, 60 to $70 \%$ of the biomass and nutrient yield in the fertile pasture occurred in the spring. In this period, the occupancy of the pasture - manifested in the number of ewes with lambs - can range from 10 to 14 animals per 1 ha (Jarrige, 1989). In the summer months, particularly in periods of drought, grazing should be limited by reducing the number of animal or by additional feeding. In the poor pasture, such a situation can occur much earlier (Table 1).

\section{CONCLUSIONS}

The studies were conducted in Roztocze National Park, in two pastures varying in terms of the vegetation cover. The fertile pasture, situated on a slope, was represented by the developing $L o-$ lio-Cynosuretum association, while the poor dry pasture, situated in a flat area, was represented by a community with Agrostis capillaris and a community with Hieracium pilosella.

Trifolium repens, Poa pratensis and $\mathrm{Ta}$ raxacum officinale were the dominant species, also influencing the value of the sward, in the fertile pasture, while Agrostis vulgaris, Cirriphyllum piliferum, Achillea millefolium and Hieracium pilosella were the dominant species in the poor pasture.

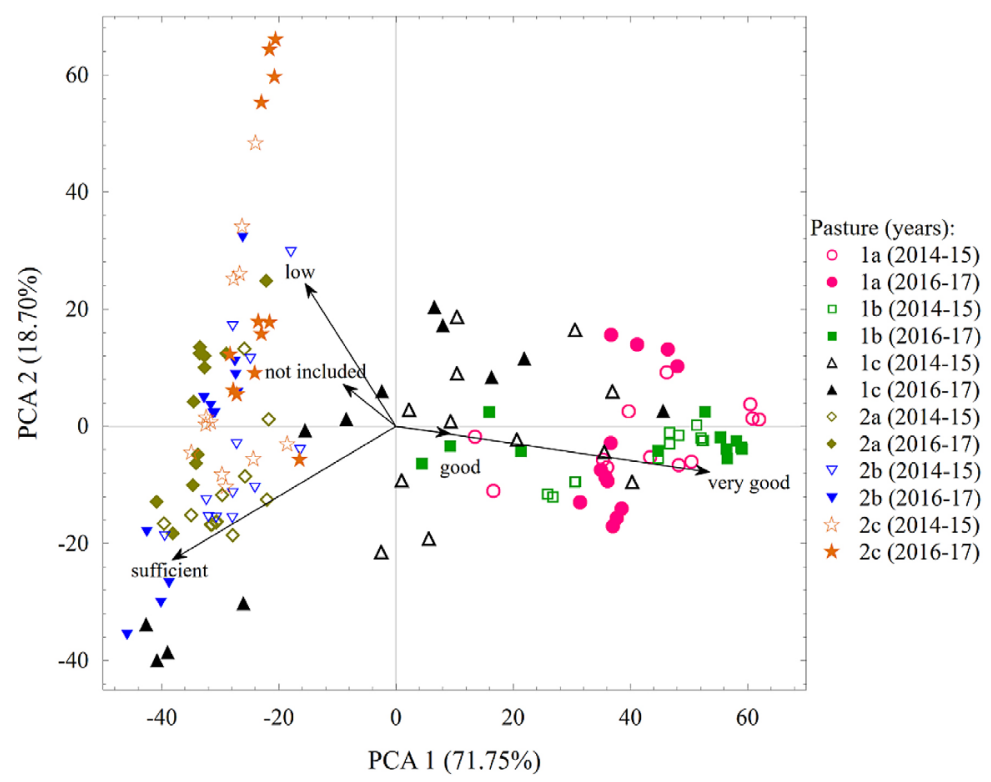

Figure. 2 Principal Component Analysis (PCA) ordination graph of sward value according to Filipek (1973) depending on the pasture and study period 
Table 2. Content and yield of nutrients in biomass

\begin{tabular}{|c|c|c|c|c|}
\hline \multirow{2}{*}{ Nutrient/Years } & \multicolumn{2}{|c|}{ Pasture 1} & \multicolumn{2}{|c|}{ Pasture 2} \\
\hline & 2016 & 2017 & 2016 & 2017 \\
\hline Crude protein - CP (\% DM) & $\begin{array}{l}12.64^{\mathrm{a}} \\
\pm 0.50\end{array}$ & $\begin{array}{l}13.26^{\mathrm{a}} \\
\pm 0.96\end{array}$ & $\begin{array}{l}19.70^{\mathrm{b}} \\
\pm 1.62\end{array}$ & $\begin{array}{c}12.70^{\mathrm{a}} \\
\pm 1.69\end{array}$ \\
\hline PDI (\% DM) & $\begin{array}{l}3.50^{\mathrm{a}} \\
\pm 0.00\end{array}$ & $\begin{array}{l}3.52^{\mathrm{a}} \\
\pm 0.00\end{array}$ & $\begin{array}{l}3.51^{\mathrm{a}} \\
\pm 0.00\end{array}$ & $\begin{array}{r}3.50^{\mathrm{a}} \\
\pm 0,00\end{array}$ \\
\hline Crude fibre (\% DM) & $\begin{array}{c}19.74^{\mathrm{b}} \\
\pm 0.60\end{array}$ & $\begin{array}{c}28.26^{c} \\
\pm 1.98\end{array}$ & $\begin{array}{l}10.35^{\mathrm{a}} \\
\pm 1.38\end{array}$ & $\begin{array}{c}27.00^{\circ} \\
\pm 1.82\end{array}$ \\
\hline NEF (\% DM) & $\begin{array}{c}57.08^{\mathrm{bc}} \\
\pm 0.84\end{array}$ & $\begin{array}{c}42.49^{a} \\
\pm 3.70\end{array}$ & $\begin{array}{c}55.49^{\mathrm{bc}} \\
\pm 2.74\end{array}$ & $\begin{array}{c}50.35^{\mathrm{b}} \\
\pm 2.11\end{array}$ \\
\hline GE (MJ ha ${ }^{-1}$ of DM) & $\begin{array}{l}17.52 \\
\pm 0.28\end{array}$ & $\begin{array}{l}17.04 \\
\pm 0.95\end{array}$ & $\begin{array}{l}17.56 \\
\pm 0.30\end{array}$ & $\begin{array}{l}18.10 \\
\pm 0.10\end{array}$ \\
\hline ME (MJ ha ${ }^{-1}$ of $\left.\mathrm{DM}\right)$ & $\begin{array}{l}8.59^{\mathrm{ab}} \\
\pm 0.13\end{array}$ & $\begin{array}{l}8.01^{\mathrm{a}} \\
\pm 0.50\end{array}$ & $\begin{array}{l}8.35^{\mathrm{ab}} \\
\pm 0.06\end{array}$ & $\begin{array}{l}8.68^{b} \\
\pm 0.05\end{array}$ \\
\hline UFL $\left(\mathrm{kg}^{-1}\right.$ of DM) & $\begin{array}{l}0.70^{\mathrm{b}} \\
\pm 0.01\end{array}$ & $\begin{array}{l}0.65^{\mathrm{a}} \\
\pm 0.04\end{array}$ & $\begin{array}{l}0.68^{\mathrm{ab}} \\
\pm 0.00\end{array}$ & $\begin{array}{c}0.70^{\mathrm{b}} \\
\pm 0.01\end{array}$ \\
\hline Yield of DM $\left(\mathrm{t} \mathrm{ha} \mathrm{h}^{-1}\right)$ & 6.2 & 6.5 & 1.9 & 3.5 \\
\hline Yield of CP $\left(\mathrm{kg} \mathrm{ha}^{-1}\right)$ & 807 & 853 & 243 & 438 \\
\hline Yield of UFL $\left(\mathrm{kg} \mathrm{ha}^{-1}\right)$ & 4016 & 3625 & 1336 & 2441 \\
\hline
\end{tabular}

abc homogeneous groups; PDI - protein digested in the small intestine; UFL - feed unit for lactation; NEF - net energy fattening; GE - gross energy; ME - metabolisable energy; DM - dry matter

The greatest changes over time were observed in the mowed site in the fertile pasture (increased share of tall grasses: Dactylis glomerata and Festuca arundinacea) and in the unused site in the poor dry pasture (increased share of herbs and weeds).

Livestock grazing conducted from 2010 influenced the stabilisation of the species composition. Tree and shrub seedlings were not observed in the sward of the pastures because they were systematically eaten by the grazing livestock, which evidences a positive impact of grazing on the preservation of permanent grasslands in Roztocze National Park where forest ecosystems predominate.

The assessment of the species composition and yielding indicated that the fertile pasture was characterised by good value while the poor pasture - low or sufficient value. In terms of nutrient yield and content, these pastures were poor or very poor, and their nutritive potential was largely dependent on the meteorological conditions.

While the livestock density in the pastures, ranging from 1.1 to $1.5 \mathrm{LSU} \mathrm{ha}^{-1}$ in the years under study, was appropriate, grazing should be limited in the summer months, particularly in periods of drought, by reducing the number of animals or by additional feeding to ensure their welfare.

\section{Acknowledgments}

This work was supported by the National Centre for Research and Development in Poland within the framework of the strategic RandD programme "Environment, agriculture and forestry" BIOSTRATEG, under Grant "The uses and the conservation of farm animal genetic resources under sustainable development", contract number BIOSTRATEG2/297267/14/NCBR/2016

\section{REFERENCES}

1. Aldezabal, A., Moraguesb, L., Odriozolaa, I., and Mijangosb, I. (2015). Impact of grazing abandonment on plant and soil microbial communities in an Atlantic mountain grassland. Applied Soil Ecology, 96, 251-260. https://doi.org/10.1016/j. apsoil.2015.08.013

2. Allen, E., Sheaffer, C., and Martinson, K. (2013). Forage nutritive value and preference of coolseason grasses under horse grazing. Agronomy Journal, 105, 3, 679-684.https://doi.org/10.2134/ agronj2012.0300

3. Barańska, K., Żmihorski, M., and Pluciński, P. (2013). Raport z projektu Ochrona muraw kserotermicznych w Polsce - teoria i praktyka LIFE08 NAT/PL/513. Świebodzin: Wydawnictwo Klubu Przyrodników, 1-109. (In Polish.) 
4. Benthien, O., Braun, M., Riemann, J.C., and Stolter, C. (2018). Long-term effect of sheep and goat grazing on plant diversity in a semi-natural dry grassland habitat. Heliyon, 4, 1-17.https://doi.org/10.1016/j. heliyon.2018.e00556

5. Braun-Blanquet, J. (1964). Plant sociology. The study of plant communities. Ed. 3. Wien-New York: Springer Publishing, 865.

6. Chabuz, W., Kulik M., Sawicka-Zugaj, W., Żółkiewski, P., Warda, M., Pluta, M., Lipiec, A., Bochniak, A., and Zdulski, J. (2019). Impact of the type of use of permanent grasslands areas in mountainous regions on the floristic diversity of habitats and animal welfare. Global Ecology and Conservation, 19. https://doi.org/10.1016/j.gecco.2019. e00629

7. Dobrowolska, D. (1993). Normy żywienia bydła, owiec i kóz: wartość pokarmowa pasz dla przeżuwaczy. DC: Institute of Animal Production, Kraków. (In Polish.)

8. Dostálek, J., and Frantík, T. (2008). Dry grassland plant diversity conservation using low-intensity sheep and goat grazing management: case study in Prague (Czech Republic). Biodiversity Conservation, 17, 1439-1454. https://doi.org/10.1007/ s10531-008-9352-1

9. Filipek, J. 1973. Projekt klasyfikacji roślin łąkowych i pastwiskowych na podstawie liczb wartości użytkowej. Postępy Nauk Rolniczych 4, 59-68. (In Polish.)

10. Futa, B., Patkowski, K., Bielińska, E.J., Gruszecki, T.M., Pluta, M., Kulik, M., and Chmielewski, Sz. (2016). Sheep and horse grazing in a large-scale protection area and its positive impact on chemical and biological soil properties. Polish Journal of Soil Science, XLIX/2, 111-122. https://doi.org/10.17951/ pjss.2016.49.2.111

11. Gallet, S., and Roze, F. (2001). Conservation of heathland by sheep grazing in Brittany (France): Importance of grazing period on dry and mesophilous heathlands. Ecological Engineering, 17, 333-344. https://doi.org/10.1016/s0925-8574(00)00136-1

12. Gaweł, E., Grzelak, M., and Madej, A. (2016). Ocena produkcyjno-ekonomiczna wydajności runi bobowato-trawiastej w zależności od składu gatunkowego mieszanek i sposobu użytkowania. Roczniki Naukowe Stowarzyszenia Ekonomistów Rolnictwa i Agrobiznesu, 18, 2, 95-101. (In Polish.)

13. Gruszecki, T.M., Pięta, M., Lipecka, C., Szymanowska, A., Junkuszew, A., Greguła-Kania, M., Patkowski, K., Szymanowski, M., and Bojar, W. (2013). Owca uhruska i syntetyczne linie BCP i SCP na Lubelszczyźnie. Lublin: ALF-GRAF. (In Polish.)

14. Jarrige, R. (1989). Ruminal nutrition: Recommended allowances and feed tables. Paris: DC: INRA, 389.
15. Jolliffe, I. T. (2002). Principal Component Analysis. Second edition Springer-Verlag.

16. Kulik, M., Warda, M., and Leśniewska, P. (2013). Monitoring the diversity of psammophilous grassland communities in the Kózki Nature Reserve under grazing and non-grazing conditions. Journal of Water and Land Development, 19(VII-XII), 59-67. https://doi.org/10.2478/jwld-2013-0017

17. Lipiec, A., Gruszecki, T.M., Warda, M., Bojar, W., Junkuszew, A., Kulik, M., and Greguła-Kania, M. (2015). Nutritional well-being of sheep under freerange grazing system on natural dry grasslands. Medycyna Weterynaryjna, 71(1), 41-45.

18. Matuszkiewicz, W. (2008). Polish plant communities guidebook. Ed. PWN Warszawa, pp. 536. (In Polish.)

19. Mirek, Z., Piękoś-Mirkowa, H., Zając, A., Zając, M. (2002). Flowering plants and pteridophytes of Poland a checklist. Kraków: Institute of Botany, Polish Academy of Sciences, 442.

20. Neal, J.S., Fulkerson, W.J., Lawrie, R., and Barchia, I.M. (2009). Difference in yield and persistence among perennial forages used by the dairy industry under optimum and deficit irrigation. Crop and Pasture Science, 60, 11, 1071-1087. https://doi. org/10.1071/cp09059

21. Nienartowicz, A., Lewandowska-Czarnecka, A., Ortega, E., Deptuła, M., Filbrandt-Czaja, A., and Kownacka, M. (2015). Afforestation of heathlands and its influence on the land cover, accumulation of plant biomass and energy flow in the landscape: An example from Zaborski Landscape Park. Ecological Questions, 21, 91-99. https://doi.org/10.12775/ eq.2015.016

22. Paskudska, A., Kołodziejczyk, D., and Socha S. (2018). Wykorzystanie ziół w żywieniu zwierząt gospodarskich. Acta Scientiarum Polonorum Zootechnica, 17(2), 3-14.

23. Patkowski, K., Pluta, M., Lipiec, A., Greguła-Kania, M., and Gruszecki, T. (2018). Foraging behaviour patterns of sheep and horses under a mixed species grazing system. Journal of Applied Animal Welfare Science, 1-7. https://doi.org/10.1080/10888705.20 18.1522505

24. Pilliner, S. (2008). Praktyczne żywienie koni i kuców. Warszawa: SIMA WLW. (In Polish.)

25. Pluta, M. and Osiński, Z. (2018). Dobre praktyki w żywieniu koni. Pasze Przemysłowe, XXVII, 3, 65-76. (In Polish.)

26. Sewerniak, P., and Jankowski, M. (2015). Deforestation increases differences in morphology and properties of dune soils located on contrasting slope aspects in the Torun military area (N Poland). Ecological Questions, 21, 61-63. https://doi. org/10.12775/eq.2015.009 
27. Steinshamn H., Grøva L., Adler S. A., Brunberg E., and Lande U.S., 2018. Effects of grazing abandoned grassland on herbage production and utilization, and sheep preference and performance. Frontiers in Environmental Science, 6, 1-12. https://doi. org/10.3389/fenvs.2018.00033

28. Süss, K., and Schwabe, A. (2007). Sheep versus donkey grazing or mixed treatment: Results from a 4-year field experiment in Armerio-Festucetum trachyphyllae sand vegetation. Phytocoenologia, 37, 135-160. https://doi.org/10.1127/0340-26 9X/2007/0037-0135

29. Süss, K., Storm, C., Zehm, A., and Schwabe, A. (2004). Succession in inland sand ecosystems: which factors determine the occurrence of the tall grass species Calamagrostis epigejos (L.) Roth and Stipa capillata L.? Plant Biology, 6, 465-476. https://doi.org/10.1055/s-2004-820871

30. Szajda, J., and Łabędzki, L. (2016). Estimation of actual yield of grassland on the basis of maximum yield and soil water potential. Water-EnvironmentRural Areas, 16, 1, 93-114.

31. Töröka, P., Valkóa, O., Deáka, B., Kelemena, A., Tóthb, E., and Tóthmérésza, B. (2016). Managing for species composition or diversity? Pastoral and free grazing systems in alkali steppes. Agriculture, Ecosystems and Environment, 234, 23-30. https:// doi.org/10.1016/j.agee.2016.01.010

32. Warda, M., Kulik, M., and Gruszecki, T. (2011). Charakterystyka wybranych zbiorowisk trawiastych w rezerwacie przyrody „Kózki” oraz próba ich czynnej ochrony przez wypas owiec rasy świniarka. Annales UMCS E, 46(4), 1-8. DOI: 10.2478/ v10081-011-0009-5 